\title{
Orthoepical potential of speaking in the Yakut language
}

\author{
Ivan Alexeyev ${ }^{1, *}$, and Irina Sorova ${ }^{1}$ \\ ${ }^{1}$ North-Eastern Federal University named after M. K. Ammosov, 677000, 58 Belinsky ul., Yakutsk, \\ Russia
}

\begin{abstract}
The article deals with the study of the general Yakut speaking base - articulation as a model. It forms the orthoepical potential of the Yakut language. Patterns of interaction of language and intonational structures of a separate word, word-combination and communicational types of phrases are defined. Criteria of speaking behavior are also defined, on the basis of which indicators of correctness of perceived acoustic parameters of articulated speech signals are revealed. This whole complex of articulatory-acoustic speech indicators allows to consider speech signal as not only physiological formation, but also as indispensable designer of cogitative sides of speaking act. Therefore, in standard peculiarities of Yakut speaking, specific parameters are formed, due to which judgmental potential of speech model is typologically formed. Logically-grammar peculiarity of speaking act as semantically important object forms standard feature of idea. Consequently, discussed acoustic parameters of existing Yakut speaking establish defining their communicational formula of types of utterances.
\end{abstract}

The problem of orthoepy in altaism (languages of Altai region) has not been properly developed yet. Being established as a language phenomenon, research on correct articulation of sounds, syllables, word-combinations and utterances, as well as a nature of verbal and phrasal stress can be found in works of phonologists, comparativists and phoneticians like N. S. Trubetskoy [1, p. 230], A. N. Kononov [2, p. 51], N. P. Dyrenkova [3, p. 39], U. Sh. Baychura [4, p. 181-182], N. D. Dyachkovsky [5; 6]. In fact, basics of orthoepical standards of sounds' articulation in word-forms and utterances of most languages of peoples of Siberia and Far East were developed in experimental laboratories of Novosibirsk, Yakutsk, Ulan-Ude and Kyzyl. They compose scientific base for formation of orthoepical systems of each certain language (Buryat, Tuvinian, Altai, Evenk and Yakut). Even comparative analysis of morphemic categories of Altai languages with mainland Altai ones, gives a cue to standard articulations of morphemes like тук 'стук'knock' [7, p. 57-64]. Consequently, to trace the formation of orthoepical rules in a language and compared to relative languages, it is necessary to determine common criteria, which contribute to objective and correct analyses of parameters (the so-called

\footnotetext{
* Corresponding author: isorova@mail.ru
} 
differentiators [8, p. 66-68]) of orthoepical formations in a language. Such criteria are prosodic indicators of phonemes, syllables, words and utterances, that help to determine formal structures, semantic aspects of intonational language levels [9, p. 10-27]. Orthoepy has been general in determination of intonational units and language systems, its functions lead to logically-grammar and syntactic comprehension of speech flow [10, p. 24-33].

Link of orthoepy and logically-grammar content of utterance is inextricable. As structurally-semantic speech layer is built up on prosodic parameters, they establish clarity and definition of perceived idea, which are guided by judgment as an exponent of communicational type of utterance [11, p. 39-45].

Determination of orthoepy in phonetic works is unique, because it is primary towards spelling and is a model of articulate correctness, use of any sounds in a word or utterance in general $[12$, p. $6 ; 13$, p. $37 ; 14$, p. 295]. Besides the modern orthoepical standard in each developed language group (peoples, community of language families and so on), historical orthoepy is preserved. They are reflected in the diversity of literary articulations, fairy tales and epic pieces of art (for example, "Word about Igor's regiment", Yakut olonkho and other folklore works [15, p. 119-129]). Due to teaching of historical orthoepy in the education system, speaking literacy is established. It is very important for the development of orthoepical standards of modern languages.

The aim of this research is to determine, on a basis of the Yakut language, interacting aspects of orthoepy with logically-grammar and intonational order of utterance in the Yakut language.

1. Indispensable creators of ideas and personal statements and its transmission to an interlocutor are of the coherent structure and type of utterance. Binary division of an utterance into interrogative and non-interrogative in linguistics defines their logical essence, because a communicational act of speech as judgment expands the volume of traditional understanding of a definite type of utterance - question, narrative, incentive [16, p. 88; 17 , p. $18-21 ; 8$, p. 25]. In order to feel the interaction of orthoepy with judgmental attribute of utterance, in P. V. Kopnin's opinion, such common signs as reflection of reality, truthfulness or falsehood, connection of ideas, subjectively-predicate form should be found $[18$, p. 336]. Interrogative utterance, reflecting greater logical significance represents a specific judgmental structure. As G. V. Kolshansky states that the attribute of statement or negation is peculiar only to judgment, but it is not essential attribute, as it can be present or even absent at all [19, p. 95-101].

There is another group of researchers, logicians and linguists assuming after Aristotle that the informative side of a question and incentive is structurally different than the narrative utterance. Aristotle himself excluded the informative side of a question out of logics as a subject. Therefore, he limited judgment from them as an independent type of statement. In particular, Aristotle claimed that "judgment is a speech about something, stating or negating something. Any speech has a meaning, but not every speech includes judgment, only that which implies truthfulness or falsehood of something" [20, p. 26].

The discussion of logicians on forms of ideas has found its reflection in theoretical constructions of linguists that make up third group. Academician Vinogradov V.V., for example, has a linguistic approach towards the problem of logical structure of interrogative utterance. Stating that interrogative utterance expresses inquiry or demand to define that or any action, event, subject, etc., he stresses on difference of questions by content, form and modal meanings, that is actually uttered, stated or understood in a question [21, p. 94].

Different idea on judgmental interpretation of interrogative utterance was mentioned by V. E. Shevyakova: "If judgment has a subject (S), predicate (P) and link (l) $-\mathrm{S}+1+\mathrm{P}$ or $\mathrm{P}+1+\mathrm{S}$, then this question is a task with only "one unknown". When predicate is known, the subject and link are present in the question $-(\mathrm{S}+1-\mathrm{X})$ or $(\mathrm{X}+1+\mathrm{S}) »[22, \mathrm{p}$. 79]. It should be noted that whether formally-grammar means created types of utterances, obligatory mean 
of realization, for instance, interrogative meaning has been intonation. It imparts speech segments completeness - predicativity, turning them into smallest unit of communication utterance; expresses semantic centre of statement - rem; determines communicational type of utterance (question, statement, incentive) [11, p. 38].

Phoneticians-experimenters studying like logicians and grammarians structurallyintonational, logically-semantic peculiarities of utterance, established that one of the essential moments postulated judgmental interpretation of all idea forms is a logical structure $\mathrm{S}-\mathrm{P}$, peculiar to all idea forms without exception, and this structure obviously or not obviously was referred characteristic to judgment only. However, it is more practical to assume logical structure S - P peculiar to any idea in general, as well as judgment. So, judgment along with incentive and question should be considered as particular idea forms. There is a dispute among linguists on logical terms - whether to consider generic the definition of a judgment, assuming that narrative, question and incentive as specific idea forms, or to consider the judgment as a specific idea form, assuming the definition of an idea as generic definition, represented in forms of judgment, question or incentive. We suppose that such essential moment is a structure of idea itself, especially S-P. In particular, specific idea form - question has the same structure $S-P$. Consequently, difference of specific idea forms should be in ratio between S-P. The subject of idea is denoted by the term of subject and its symbol S. If structural component of idea predicate $\mathrm{P}$ is attached significance of subject's $\mathrm{S}$ characteristics in the broadest sense, then the difference in concrete structures of specific idea forms - judgment, question, incentive can be reduced to the difference of ratios between $\mathrm{S}$ and $\mathrm{P}$ in the structure of idea. The judgment is characterized by statement on unawareness of one out of two components, that is ratio of known-unknown in structure S - P: Кимкэлэр? 'Kто придет?' 'Whowillcome?'; Кини ханнаный? 'Где он?' 'Where is he?'. The incentive is characterized by possibility of realization-unrealization P for the ratio S: Киникэллин. 'Пусть он придет'; 'Lethimcome', Кини кэлбэтин. 'Пусть он не придет' 'Don 'tlethimcome'.

All this logically-grammar system, considering semantic structure of utterance in a form of communicational setting, can be presented in a following table.

Table 1. IdeaS - P.

\begin{tabular}{|l|l|l|}
\hline \multicolumn{1}{|c|}{ Specific form } & \multicolumn{1}{|c|}{ Content of an idea } \\
\hline Judgment(narrative) & \multicolumn{1}{|c|}{$\begin{array}{c}\text { External } \\
\text { (ratio S - P) }\end{array}$} & \multicolumn{1}{c|}{$\begin{array}{c}\text { Internal } \\
\text { (ratio between S and P) }\end{array}$} \\
\hline Question & $\begin{array}{l}\text { The wish to know content of } \\
\text { unknown inS }-\mathrm{P} \text { (which is } \\
\text { unknown in P, or inS, or inS }-\mathrm{P} \text { ) }\end{array}$ & $\begin{array}{l}\text { Obsence/absence: subjectivity P } \\
\text { inS - P }\end{array}$ \\
\hline Incentive & $\begin{array}{l}\text { The wish of realization P inS }-\mathrm{P}: \\
\text { (let it be/ not let it be P in S) }\end{array}$ & $\begin{array}{l}\text { Conditional realization or }- \text { PinS - P } \\
\text { subjectivity P inS }-\mathrm{P}\end{array}$ \\
\hline
\end{tabular}

Specific idea forms presented in the table can really exist and actually exist in utterances only.

Such theoretical interpretation of nature of an utterance, its typical, specific and communicational realizations should be based on primordially stable articulate-semantic factors of speech by all means, they are based on orthoepical language patterns [11, p. 4345].

1. Second important indicator of speaking behavior's correctness is intonation, which is not only part of phonetics or syntax, but also a system of linguistic units of distinct level of language system [8, p. 3]. Only in a speaking act, intonational models are formed, where various forms of communication interact with speaking situation and situation of utterance formation. Structurally, the utterance presents semiotic idea expression - sentence. The 
term sentence in modern linguistics implies two phenomena: model of sentence and its speech realization - utterance [8, p. 7], in other words, utterance is a realization of a sentence in a speech, intonated by means of correct articulation - orthoepy. However, semantic integrity of intonation is achieved, besides compliance (use) of orthoepical standards, by a number of language elements: system of a language, language standards, usus (social standard and individual speech). Anyhow, in all deviancy of intonational structures of a language "utterance is speech segment, having communicational direction, semantic integrity, which is realization of language system that meets language standards" [10, p. 13-15].

Each utterance is expressed by intonation, totality of prosodic means, taking part in division and organization of speech flow in accordance with the meaning of statement transmitted $[10$, p. $15 ; 11$, p. 257). Obligatory structure of intonational line is formed, it contributes into formation of clarity and definition of communicational type, syntactic order and lexical filling of an utterance.

Intonation as a defining factor in utterance "unites" all language units, starting from structural outline of a sentence ( $\mathrm{S}-\mathrm{P}$ and its subdivisions), ending up to its interacting components - length, tonality, dynamics, timbre and temporal characteristics. These versatile structurally-intonational indicators of utterance, including implication - pause, cannot be considered in syntax [8, p. 28-29].

In identification of the type of utterance, not only absolute parameters of intonation are important, but also their relative realizations in a part of communicational type of utterance. In other words, semantically important phrase segment can be realized by relatively greater intonational values. For example, in a phrase Уусуолунанбарабын. 'Поедуводнымпутем' 'I'll go by waterway' semantically important segment is by waterway (M-circumstance) is expressed byincrease offrequency of major tone (f.m.t) concerning барабын I'll go $(\mathrm{P})$ and descending tonality motion in interval of large third is formed with increased value of length. According to "wandering along the surface of a tongue" super-segment components of prosodic phenomena [23, p. 180] differentiated "equalization" of phrase intonation takes place. Such cumulative realization of physical parameters: f.m.t., intensity and length, always accompanying prosody of any value and establishing explicit and implicit network of contrasts like: higher-lower, smoothly-abruptly, quicker-slower, etc.; they make up linguistic relevance. They can be called differentiators that depend on specific language material and functioning capacity in speech flow [8, p. 66-67]. These are differentiators that being realizators of relative parameters become indicators of correctness of perceived acoustic parameters of articulated speech segments: sound, syllable, word and phrase. So, the form of f.m.t. change (melodic contour, interval, range of increase/decrease), amplitude of intensity peaks, syllables' length, rhythmic groups, syntagmas and others have been the marks of determination of correctness/incorrectness. And others serve as a basis for determination of orthoepical peculiarities of any language. Combination of minimal/maximal differentiators contribute into perception of semantically important speech segments.

2. Taking into account differentiated characteristics formed due to prosodic modulations of Yakut speech (sounds, syllables, word-forms, syntagmas and utterances) system of orthoepical standards of articulation can be formed. In some language materials, the common tendency of articulation standardization is shown up. It is reflected in traditional logically-grammar and intonational language factors. Structurally-semantic characteristics of materials accumulated, as a rule, are established by quality of articulated speech segments, along with its articulate-acoustic, accent and intonational indicators; structurallysemantic peculiarities of utterance and its separate segments are established.

On a phonological generalization, system of vocalism and consonantism of Yakut language was thoroughly analyzed in works of prof. Dyachkovsky N. D., on the basis of 
which modern orthoepical standards of Yakut literary language (articulation of specific phonemes and word-forms) [5;6]. Intonational parameters of types of utterances and spontaneous speech, studied by Alexeyev I.E. and Sorova I.N. expanded modified characteristics of sounds in a process of speech flow $[24 ; 25]$. On a level of word and syntagma/phrase, prosodic realizations alternating like allophones of phonemes, are mutually adapted as results of speech formation. Such adaptability of speech sounds generate accomodational changes between sounds of various categories [16; p.180]. In a speech flow they compose segments of progressive and regressive order of vocal and consonant components of prosodic phenomena. All these peculiarities of articulation of all types of utterances express intonational realization closely connected with semantics of certain utterance (any value of speech segment).

With the appearance of new methods of analysis of speech signals, it became possible to observe more "cryptic" speech signs that contribute into the generalization and identification of basic rules of orthoepy, for example, Yakut speech. The work in this field of Yakut linguistics is carried out sporadically since the times of founder of Yakut writing Novgorodov S.A. [26, p. 11]. Although, for the long time disputes on determination of spelling rules of Yakut language "outmatched" the work on orthoepy and only starting from the issue of M.P. Alexeev's works on a culture of speech, studies on Yakut orthoepy were revived [27, p. 11-13].

On the basis of collectively done researches in a laboratory of experimental philology named after prof. Dyachkovsky N.D., with collaboration of Alexeev M.P. some rules of traditional articulate standards were revealed. They were mentioned in books of Novgorodov S.A. «Аақаркинигэ (Book for reading)» (1923). For example, change of consonants at the junction of word-forms in a phraseүстиидаттыгар'возлетрехлиственнии', 'nеar two larches';, иккиһуол 'дверазновидности','two kinds'; ынахыаммытынкэннэ 'последойкикоров', 'after milking the cow'; ордукүүттээБбуолар 'молокабольшечем...', 'milk more than'; кэпсэнэринкурдук 'какговорится', 'as it is said'; өрүстиэки 'всторонуреки', 'towards the river' and others.

However, for the last decades due to absence of standard rules and spelling dictionaries for schools, as Alexeev M.P. established, deviancy from usual parameters of articulation occur; so speaking is looking towards "book language". In speaking process spelling standards prevail orthoepical. For instance, Novgorodov S.A. had a principle "write as it is spoken", but at present it became "speak as it is written". For the standardization of established speaking situations at the Institute of languages and culture of peoples, scientific work "Orthoepy of Yakut language" has been started, according to this it is planned to develop works like "The Rules of Yakut orthoepy" and "Orthoepical dictionary of Yakut speech". Test articles "the Rules", proved by experimental findings with the use of «SpeechAnalyzer», are used in educational process in North-Eastern University named after Ammosov M.K., and some of them are published as "Preface" in the work mentioned above Alexeev M.P. «Ийэтыл» (Native language). There are some abstracts:

1. In a speech flow at the joint of word-form, final deaf consonant is vocalized under the influence of primary sonant of following word: оннугбуоллақа 'значиттак', 'the way it is '; омугбаар 'естьтакойнарод', 'there is such nation';килиэббурдуга 'мукадляхлеба', 'flour for bread'; сөбдиэтэ 'сказал, чтоверно', 'said that's right';барбыддьон 'ушедшиелюди', 'the реорle gопе'; оннугэбиддиэтэ 'сказал, чтоточнотак' 'said, that's true';

2. At the joint of word-form final nasal $\mu$ under the influence of primary $\sigma, \kappa, \mu$ of following word it is transformed and becomes см, н: симбиир 'всеравно', 'I don't care'; бииртэмбиир 'другзадругом', 'оnе after another'; aтыммииммит 'селверхом', 'he rode the horse'; тылынкыбыппыт 'высказался', 'he spoke out'; 
3. At the joint of word-form, final combination $p m$ under the influence of primary $\sigma, \partial$ of following word is articulated likemorn (in Yakut language, combination of tree consonants is absent):бэпбуолла5а 'хорошоже', 'that's good'; түөпбиэрэстэ 'четырекилометра', 'four kilometers'; бэтдақаны 'какхорошо' 'this is so great';

4. At the joint of word-form, final deafmunder the influence of primary $\sigma, \mu$ of following word it's articulated like $n$ : опбы hар 'сенокосит (режет)', 'mowing the hay'; оспопбаас 'незажсивающаярана', 'unhealed wound'; хайдахсатаммапбуолуой 'получитсяжеведь', 'we're gonna make it'; хомуйбупмаспыт 'дрова, которыемысобирали', 'the woods we gathered'; опмунньар 'сенособирает', 'gather the hay';

5. Finalmof the first word under the influence of first sound $\partial, \partial b, \mu$, cof following word are vocalized liked: барбыддьон 'ушедшиелюди','реорlе gопе'; самнайбыддьиэ 'ветхоежилище', 'shabby dwelling'; төрудноруот 'кореннойнарод', 'indigenous реорle'; сөбүлээбэдсуола 'непонравится (ему) это', 'he wouldn't like it';

6. In a word-combinationmof first word under the influence of first soundxof second word is articulated likex: yoxхарахха 'mочьвточь', 'exactly the same'; blччаххаһblama 'молодежнаягазета', 'young pеople's nеwspaper'; оххарбыьр 'собираетсено', 'gather the hay';

7. In a word combination final xof first word under the influence $\sigma, \partial, \partial b, \kappa, \mu$ of following word is articulated like sonant5: олоқбарбыт 'навсегдаушел', 'he left for good'; кыахтааббуоллақына 'еслиосилит', 'if he manages to do'; суобдииллэр 'говорятженет', 'уои were told No'; хайда5даa 'чтоговоришь', 'what are talking about', омсолооьдьоруой 'отрицательныйгерой', 'negative character', со5отоБкиһи 'одинокийчеловек', 'lonely таn', олохтооқноруот 'кореннойнарод', 'indigenous people';

8. Under the influence of primary consonants $u, o, y y, Y$, эо word combination's second word final mof first word transfers toд: сөллүбэдини 'неразвяжется, наверно', 'probably, it wouldn't untie',төрүдомуктар 'коренныенародности', 'indigenous peорle', кэспидуубут 'знакомыйброд', 'ford we know', суруллубудүлэ 'завершенныиттруд', 'the complete work', билбэдэрээри 'незнаешьже', 'not even knowing', баБарбадэтэ 'нехотелже', 'he didn't even want that';

9. Articulation of specific words, like divided speech units, also have rhythmicallymelodic structure, corresponding to its semantic significance.

Modifications of border consonant-consonant and consonant-vocal segments in speech flow, mentioned by Novgorodov S.A. characterize orthoepical standard and modern speakers of Yakut language. Identified findings are observed in two speakers. Deaf [t] before sonant [в] (fig. 1, 2) and deaf [t] before vowel [0] (fig. 2, 3) are vocalized and articulated within limitsof 145-160 Hzof general frequency motion of large third. A quantitative realization of vocalized $k$ and $t$ varies from interval $80-110 \mathrm{~ms}$, that makes up 8$11 \%$ of general phrase length.

Intonational model of utterance forms, on the whole, monotonous-descending (speaker PGG) and descending enclitic increase (speaker GGI) curves with general interval of frequency motion of large third within limits of f.4 (quarter) - f.5 (fifth).Consequently, experimentally-linguistic study of orthoepical diversities, starting from specific phonemes and ending up to phrase, utterance, has been one of the outmost tasks of not only Yakut language, but also other languages as well, that function on a territory of the Sakha Republic (Yakutia).

In given orthoepical rules of first order, there is general pattern of language reality that prosodic elements of articulation are the results of interrelation of differentiators: relative parameters of intonated of speech segments determine formally-structural essence of a word, word combination and whole utterance. Consideration of relevant qualities of intonated speech segments, in a set of orthoepical values, as is known, is based on variation 
of canonic forms of articulated speech (types of utterances, modality, extra-linguistic factors and others)

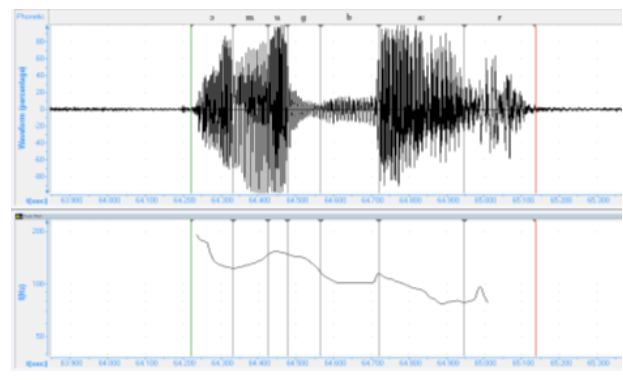

Fig.1. (s.GGI) Омукбаaр [эmugba:r]

'There's such nation'

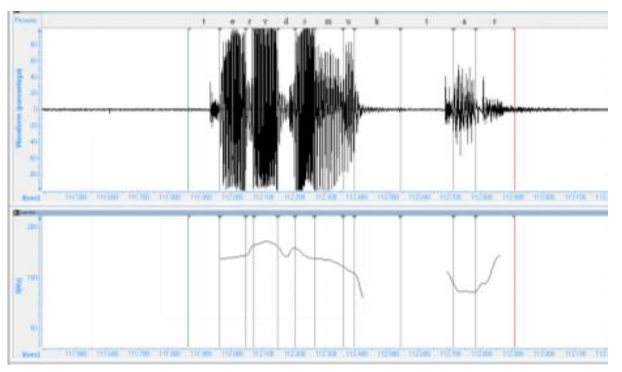

Fig. 3. (s.GGI) Төрүтомуктар [terYdomuktar] 'Indigenous people'

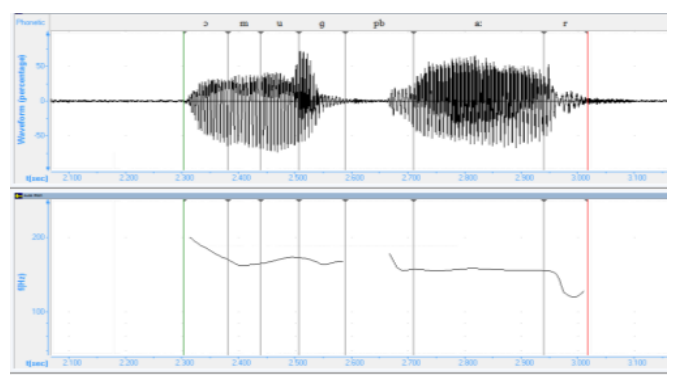

Fig.2. (s.FGG) Омукбаар [эmugpba:r]

'There's such nation'

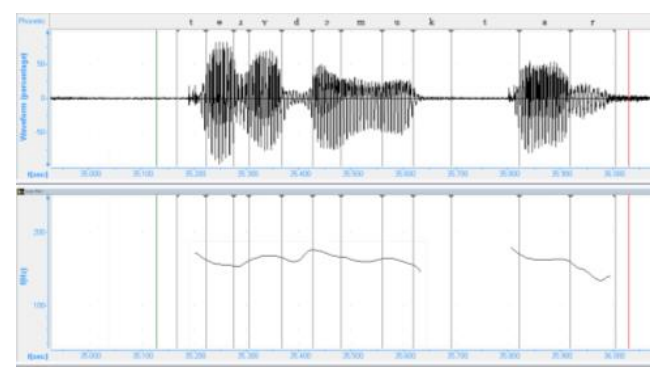

Fig.4. (s.PGG) Төрүтомуктар [terYdəmuktar]

'Indigenous people'

Therefore, intonation is not the only defining factor of formation of speech segment of any value. In expression, for example, of orthoepical speech units, all language units equivalently take part, starting from structural word outline ending up to their intonated values.

\section{References}

1. N. S. Trubetskoy, Basics of Phonology, p. 372 (Moscow,1960)

2. A. N. Kononov, Grammar of modern Turkish literary language, p. 569 (AN USSR publishing house, Moscow-Leningrad, 1956)

3. N. P. Dyrenkova, Grammar of Oirat language, p. 303 (Moscow-Leningrad, 1940)

4. U. Sh. Baychura, Problems of Turkology and history of Orientology, pp. 181-182 (Kazan, 1964)

5. N. D. Dyachkovsky, Acoustic order of Yakut language. Part 1 Vocalism, pp. 191 (Yakutsk publishing house, Yakutsk, 1971)

6. N. D. Dyachkovsky, Acoustic order of Yakut language. Part 2 Consonantism, pp. 256 (Yakutsk publishing house,Yakutsk, 1977)

7. N. A. Syromyatnikov, The problem of community of Altai languages, pp. 57-64 (Science, Leningrad,1971)

8. I. G. Torsuyeva, Intonation and meaning of utterance, p. 109 (Science, Moscow, 1979)

9. T. M. Nikolayeva, Phrasal intonation of Slavonic languages, p. 281 (Science, Moscow,1977) 
10. N. D. Svetozarova, Intonational system of Russian language, p. 176 (Publishing house of LSU, Leningrad,1982)

11. I. E. Alexeyev, Interrogative sentence in Yakut language, p. 172 (Yakutsk, 1982)

12. M. I. Matysevich, Modern Russian language. Phonetics, p. 288 (Prosveshenye, Moscow,1976)

13. L. R. Zinder, Genaral phonetics, p. 312 (Vysshaya shkola, Moscow, 1979)

14. O. S. Akhmanova, The dictionary of linguistic terms, p. 608(Soviet encyclopedia, Moscow, 1969)

15. Y. P. Marchenko, Expressive reading, pp. 119-129 (Moscow, 1963)

16. Russian Grammar.Volume II. Syntax, p. 710 (Science, Moscow, 1980)

17. L. I. Iliya, Foreign languages at school, p. 18-21 (Vysshayashkola, Moscow,1962)

18. P. V. Kopnin, Intellection and language, p. 276-351 (Moscow, 1957)

19. G. V. Kolshansky,Logics and structure of language, p. 240 (Moscow, 1965)

20. Aristotle, Analytica Priora and Posteriora, p. 440 (Gospolitizdat, Moscow, 1952)

21. V. V. Vinogradov, Questions of syntax of modern Russian language, p. 75-126 (Uchpedgiz, Moscow, 1950)

22. V. E. Shevyakove, Modern English, p. 381 (Science,Moscow, 1980)

23. A. M. Peshkovsky, Intonation and grammar. Selected works, p. 250 (Moscow, 1959)

24. I. E. Alexeyev, Typology of structurally-communicational and intonational systems of utterances in Yakut language.Thesis for attainment of a scientific degree, p. 58 (Almaty,1994)

25. I. N. Sorova, Phonostylistics of Yakut speaking (experimentally-linguistic research). Thesis for attainment of scientific degree, p. 23 (Yakutsk, 2011)

26. S. A. Novgorodov, The book for reading, p. 168 (Moscow-Saint Petersburg, 1923)

27. M. P. Alexeev, Ancient traditions of Sakha language and its devations, p. 494 (Yakutsk, 2013) 